NBER WORKING PAPER SERIES

\title{
FINANCIAL AID AND STUDENTS' COLLEGE DECISIONS: EVIDENCE FROM THE DISTRICT OF COLUMBIA'S TUITION ASSISTANCE GRANT PROGRAM
}

\author{
Katharine G. Abraham \\ Melissa A. Clark \\ Working Paper 10112 \\ http://www.nber.org/papers/w10112 \\ NATIONAL BUREAU OF ECONOMIC RESEARCH \\ 1050 Massachusetts Avenue \\ Cambridge, MA 02138 \\ November 2003
}

The authors thank Orley Ashenfelter, Alan Krueger, David Linsenmeier, Cecilia Rouse, and seminar participants at the University of Notre Dame, the Federal Reserve Bank of New York, and the labor lunch at Princeton University for helpful comments and suggestions. Ellen Sawtell of The College Board and Diane Dickerson-Hayes of the University of the District of Columbia provided assistance with data.The views expressed herein are those of the authors and not necessarily those of the National Bureau of Economic Research.

(C)2003 by Katharine G. Abraham and Melissa A. Clark. All rights reserved. Short sections of text, not to exceed two paragraphs, may be quoted without explicit permission provided that full credit, including (C) notice, is given to the source. 
Financial Aid and Students' College Decisions: Evidence from the District of Columbia's Tuition Assistance Grant Program

Katharine G. Abraham and Melissa A. Clark

NBER Working Paper No. 10112

November 2003

JEL No. I2

\section{$\underline{\text { ABSTRACT }}$}

The District of Columbia's Tuition Assistance Grant Program (DCTAG), instituted in 1999, allows DC residents to attend public colleges and universities throughout the country at considerably lower in-state tuition rates. We use the sharp decline in the price of public colleges and universities faced by residents of the District of Columbia under DCTAG to estimate the effects of price on students' college application and enrollment decisions. Using a sample of students from nearby large cities as a control group, we find that the number and share of DC residents applying to four-year colleges increased substantially under the program, and students were considerably more likely to apply to colleges that were eligible for the subsidy. Freshmen enrollments of DC residents also increased substantially at eligible institutions, although the effect on overall freshmen enrollments of DC residents was fairly modest, suggesting that in its first year the subsidy had more of an impact on where students chose to attend than on whether they chose to attend college at all.

Katharine G. Abraham

Joint Program in Survey Methodology

and Department of Economics

University of Maryland

College Park, MD 20742

and NBER

kabraham@survey.umd.edu

Melissa A. Clark

Mathematica Policy Research

600 Alexander Park

Princeton, NJ 08540

mclark@mathematica-mpr.com 


\section{Introduction}

How college price influences students' decisions about whether and where to attend is a question important to policymakers, university administrators, and education researchers alike, but it is difficult to determine how sensitive students' application and enrollment decisions are to the prices they face at various institutions. The amount of financial aid available to students typically is correlated with individual characteristics that may influence their college decisions, and the price of individual colleges and universities is correlated with other characteristics of the institution, but determining the effect of college costs on students' decisions requires an exogenous source of variation in prices. In this paper, we utilize one such source of variation, the District of Columbia's Tuition Assistance Grant (DCTAG) program, to examine the effect of a sharp decline in public college and university prices faced by DC residents on their college application and enrollment decisions.

The DCTAG program, established in 1999, provides a substantial subsidy for DC residents to attend public colleges and universities outside the District. Specifically, the program allows qualifying DC residents to attend public colleges and universities in other states at the considerably lower "in-state" tuition rates of these institutions. This benefit is subject to an annual cap of $\$ 10,000$ and a lifetime cap of $\$ 50,000$ per student. District of Columbia residents attending private institutions in the Washington, DC metropolitan area or designated historically black private colleges and universities are eligible for a considerably smaller subsidy of $\$ 2,500$ per year.

In this paper, we examine the effect of the DCTAG program on the college application and enrollment decisions of DC residents, using students from large cities in nearby states as a control group. In particular, we examine whether there are discernible effects of the DCTAG 
program on the likelihood that DC residents graduating from high school apply to and actually enroll in college or on the kinds of schools that DC high school graduates consider and attend. We also draw conclusions regarding the broader question of the effects of financial aid and the price of college on students' college application and enrollment decisions.

There is a growing literature that explores the effects of college price on students' enrollment decisions and how these effects differ by socioeconomic status. While much of the earlier literature failed to address the potential endogeneity of college prices faced by particular groups of students, several recent studies have convincingly identified the effects of college price on college attendance, typically through evaluations of federal, state, or individual university policies that have introduced plausibly exogenous changes in the price of college for specific groups of students. ${ }^{1}$

In general, these more recent studies have implemented varied approaches and focused on different groups of students, and they have produced a range of estimates of the effect of college price on student enrollments. For instance, Linsenmeier, Rosen, and Rouse (2002) find no statistically discernable effect on enrollments of a change in the amount of aid offered to students at a major northeastern university, although they find marginally significant effects for minority students. Van der Klaauw (2002) implements a regression discontinuity design to examine the effects of financial aid offers at an east coast college and finds that a 10 percent increase in financial aid led to an 8.6 percent increase in the probability of enrollment among individuals who also applied for federal financial aid, but only a 1.3 percent increase in this probability for those who did not file for federal aid (and presumably were from higher income families).

\footnotetext{
${ }^{1}$ See Leslie and Brinkman (1988) for a review of the earlier literature and Dynarski (2002) for an excellent overview of the more recent literature.
} 
Studies of broader changes in public policy rather than of individual schools' financial aid policies are perhaps more relevant to the study of a large-scale tuition subsidy program such as DCTAG. These studies yield estimates that are similarly variable. Dynarski (2000) finds that Georgia's HOPE merit-based scholarship program increased college attendance rates among middle- and upper-income students by about 4 percentage points for each $\$ 1,000$ in aid. Through an examination of another exogenous source of variation in financial aid, the elimination of the Social Security student benefit program, Dynarski (2003) estimates that $\$ 1,000$ of grant aid increases the probability of attending college by 3.2 percentage points among children with deceased fathers (a disproportionately low-income population). Kane (1994) examines the effects of within-state changes in public university tuition and finds no statistically discernable effect of college price on enrollment of white students, but a significant effect on African-American students. Kane (2003) exploits discontinuities in the need- and merit-based Cal Grant financial aid program and finds significant effects on enrollments in the program's first year, but no statistically discernable effects in the program's second year. He estimates that his first-year results imply enrollment increases of 1.2 to 9.2 percentage points per $\$ 1000$ of aid, depending on the degree of crowd-out from other sources of aid.

Our study provides important complementary evidence on the effects of financial aid for students of both low and high socioeconomic status. Unlike most financial aid policies evaluated in previous work, DCTAG is neither need-based nor merit-based nor targeted at a specific population (such as children of deceased fathers), but is available to all DC residents meeting basic eligibility criteria, a group that represents a broad socioeconomic spectrum. In addition, previous studies have focused on college attendance rates and educational attainment. While we too examine college enrollment effects, we also possess a rich dataset containing information on 
individual students' background characteristics, SAT scores, and the colleges to which they sent these scores, which we interpret as a proxy for where they ultimately apply. These data allow us to examine the effects of financial aid policy and tuition prices on students' decisions about where to apply as well as to enroll, a question of particular interest to university administrators who attempt to attract applicants via their aid policies.

\section{Overview of the DCTAG Program}

High school graduates in most states have access to a publicly funded higher education system that includes a network of colleges and universities. The only publicly funded institution of higher education in the District of Columbia is the University of the District of Columbia, an open-admissions institution that in many respects functions more like a community college than a typical university. Early in 1999, legislation to allow District high school graduates to attend public universities nationwide at in-state tuition rates was introduced in the U.S. House of Representatives. A more restrictive competing proposal, which would have limited program coverage to public institutions in Maryland and Virginia, soon appeared in the Senate. Those favoring tuition subsidy legislation argued that it would help to stem the outflow of middle class families, especially those with school age children, from the District and create invaluable opportunities for inner city youth. Given wide bipartisan support for the idea of tuition subsidies for DC high school graduates, passage of legislation in some form was widely anticipated.

The U.S. Congress passed the District of Columbia College Access Act of 1999 into law on November 12, 1999, and the first grants awarded under the program were for the 2000-2001 academic year. Under the legislation, any recent DC high school graduate who attends an eligible public institution may receive a benefit equal to the difference between that school's in- 
state tuition and out-of-state tuition rates, up to $\$ 10,000$ per year and $\$ 50,000$ over the student's lifetime. The law originally designated all public institutions located in Maryland and Virginia as eligible institutions, and during the fall of 1999, when most graduating high school seniors were applying to colleges for the fall of 2000, students would have assumed that the DCTAG program would benefit only those attending Maryland or Virginia schools. But the law also allowed the Mayor of the District of Columbia to broaden the program's scope if he or she determined that eligible students were experiencing difficulty in gaining admission to public colleges in Maryland and Virginia. In May 2000, the mayor took this step and formally extended the program to include all public institutions of higher education nationwide.

In addition to the subsidies provided for students attending public colleges and universities, the law also provided smaller tuition subsidies for students attending private nonprofit colleges or universities located in the District of Columbia metropolitan area or private historically black colleges and universities located in Maryland and Virginia. ${ }^{2}$ Private school grants are subject to a maximum of $\$ 2,500$ per year and $\$ 12,500$ over a student's lifetime.

To be eligible for benefits under the program, a student must have been a resident of the District of Columbia for at least 12 consecutive months prior to beginning his or her freshman year of college; have graduated from high school or received a GED on or after January 1, 1998; have begun an undergraduate course of study within three years of high school graduation or receipt of the GED (extended for periods of military or Peace Corps service); be enrolled at least half-time in a course of study leading to an accredited degree; and not already hold a bachelor's

\footnotetext{
${ }^{2}$ Schools on the original list of eligible private institutions include American University, Catholic University, the Corcoran School of Art, Gallaudet University, George Washington University, Georgetown University, Howard University, Southeastern University, Trinity College, Capitol College, Columbia Union College, Maryland College of Art and Design, Washington Adventist Hospital School of Radiology, Washington Bible College, Hampton University, Marymount University, Saint Paul's College and Virginia Union University. The private school program recently was expanded, effective for the 2002-2003 school year, to cover historically black colleges and universities nationwide.
} 
degree. In 2002 the eligibility requirements were liberalized to allow older high school graduates to benefit from the program. The DCTAG program is not means tested; indeed, those who apply are not required to provide any information about their family's income or assets.

Benefits may be applied only to tuition and fees, and benefit grants are to be made directly to the eligible institution, which must agree to comply with the program's administrative requirements. If federal funding for the program is ever insufficient to meet all requests for assistance, the mayor of DC is authorized to allocate payments based on the income and need of eligible students. To date, however, funding for the program has greatly exceeded the demand for funds, and this is projected to remain true for the foreseeable future. In the DCTAG program's first year, 1,900 individuals used the grant to attend 152 participating institutions (U.S. General Accounting Office, 2002). ${ }^{3}$

\section{Data and Estimation Strategy}

\section{A. SAT Dataset}

In our study of the effects of DCTAG on students' college decisions, we analyze data from two sources. To examine the college application decisions of individual students affected by the DCTAG program, we use data from the College Board containing information on high

\footnotetext{
${ }^{3}$ It is worth noting two other programs that are available to assist DC residents in applying to and financing college, although both are on a considerably smaller scale than DCTAG. The District of Columbia College Access Program (DC CAP) provides support services to DC public high school students and to DC public high school graduates for up to five years following graduation, to help them complete their college education. Advisors located on-site at DC public high schools provide individual and group counseling, college application assistance, and help with accessing financial aid. DC CAP was launched as a pilot program in selected schools during the 1999-2000 academic year and since then has been expanded to all DC public high schools. DC CAP also provides need-based "last dollar" award scholarships of up to $\$ 2,000$ to cover costs of college attendance not covered by other financial assistance programs. Any DC public high school student is eligible to apply. The Leveraging Educational Assistance Partnership (LEAP) program grants undergraduate study awards of up to $\$ 1,000$ per year to qualifying DC residents. These need-based awards may be used at any post-secondary institution in the country. This financial assistance program has been in existence for a number of years.
} 
school students who took the SAT. Data cover the 1994 through 2001 cohorts, where a cohort is defined as the group of students who on a normal schedule would graduate from high school in the indicated year. The database includes all black and Hispanic test takers, all test takers residing in Washington DC, and a 25 percent random sample of non-black, non-Hispanic test takers in other states. Most of the variables included in the database were derived from information supplied by the test takers on the Student Descriptive Questionnaire. Variables pertaining to the individual test takers that we use in our analysis include colleges to which test scores were sent (4-digit code, up to 20 recorded in 1994-1998, up to 30 recorded in 19992001), state of residence, high school attended, type of high school attended (public, private, or other), race/ethnicity, highest level of education attained by mother and by father, and SAT math and verbal scores.

To estimate the effects of DCTAG on District students' college application decisions, we pursue a difference-in-differences approach, using students from large cities in nearby states (Baltimore, Maryland; Newark, New Jersey; Norfolk, Virginia; and Philadelphia, Pennsylvania) as a control group. To select these cities, we first identified nearby states with SAT-taking rates similar to DC's. We then selected cities from these states with populations of 200,000 or more with a high proportion of African-Americans (40 percent of the population or more), based on 2000 Census data as reported in U.S. Census Bureau (2001). ${ }^{4}$ (DC has a population of 572,059 and is 60 percent African-American.) None of the states in which the control cities are located instituted a college assistance program on anything like the scale of DCTAG over the period of interest. As the SAT dataset has information on students' state of residence and school (which can be matched to school address information), we identify SAT-takers by city based on their

\footnotetext{
${ }^{4}$ We also conducted the analysis with all test-takers from Maryland, North Carolina, Delaware, Pennsylvania, Virginia, New Jersey, and Connecticut as a control group, as well as with different sets of cities as a control group. The results are very similar and are available from the authors upon request.
} 
state of residence and their attendance at a high school located in the relevant city. We also include DC residents attending high schools located in Maryland and Virginia, as many DC residents attend suburban private schools in these states (discussed in more detail below).

Throughout our analysis, we exclude students without a valid SAT score and students who did not send their score to at least one four-year college or university. For consistency across years, we also exclude students who did not report an ethnicity (these students were missing from the 1994-98 samples provided by the College Board). Because we use high school address to match students to cities, students not reporting a valid high school code or students reporting a high school code that could not be matched to an address are excluded as well. Our results are not sensitive to any of these exclusions.

We treat a student's decision to have SAT scores sent to a college or university as a proxy for the decision to apply to that institution. ${ }^{5}$ We expect that most four-year-college-bound high school seniors in DC and the other cities in our analysis will take the SAT and will send their SAT scores to every four-year college or university to which they apply. ${ }^{6}$ As most community colleges and other two-year colleges do not require SAT scores for admission, we limit our analysis of the SAT data to students applying to four-year colleges and universities.

\footnotetext{
${ }^{5}$ Of course, sending SAT scores to a particular college is not a perfect proxy for actually applying to that college - students may send their scores to colleges to which they ultimately decide not to apply, and they may apply to colleges to which they do not send their SAT scores (for instance, if the college does not require SAT scores for admission). The ideal dataset for assessing the use of sending SAT scores as a proxy for applying to a college would contain individual-level information on both. Unfortunately, we know of no such dataset. Card and Krueger (2003) tackle this question using data for public universities in the state of California disaggregated by race/ethnicity and campus. They show that information on the number of students of a given race/ethnicity who send their SAT scores to particular campuses proxies very well for the number of students of a given race/ethnicity who actually apply to those same campuses. ${ }^{6}$ Almost all colleges and universities accept scores from either the SAT or ACT (formerly the American College Test) for admission. The vast majority of college-bound high school students in DC and the other states represented in our analysis take the SAT, however, while only a small fraction of students in each of these states takes the ACT. See Clark (2003) for more information on SAT- and ACT-taking rates across states.
} 
To examine how DCTAG affected students' college application decisions, we estimate the following model for DC students taking the SAT:

$$
Y_{i j t}=\beta_{o}+X_{i j t} \beta_{1}+\sum_{t=1995}^{2001} \alpha_{t} \delta_{t}+\varepsilon_{i j t}
$$

In this model, $Y_{i i t}$ can represent various indicators of the DCTAG program's effects - for instance, whether student $i$ graduating from high school in year $t$ sent SAT scores to any DCTAG-eligible Maryland or Virginia institution, whether the student sent scores to any DCTAG-eligible public institution anywhere in the U.S., or the number or fraction of scores that the student sent to eligible institutions. $X_{i j t}$ is a vector of individual-level characteristics that are likely to be correlated with college application decisions, including race, parental education, and type of high school (public, private, or other) that the student attends. $\varepsilon_{i j t}$ is a stochastic error term.

The sequence $\alpha_{t}$ is a set of year dummy variables, defined in the following way: $\alpha_{1995}$ equals one if the year in which the student is expected to graduate from high school is 1995 or later and zero otherwise, $\alpha_{1996}$ equals one if the student is expected to graduate in 1996 or later and zero otherwise, and so forth, for years $t=1995$ through 2001. Defined in this way, the coefficients on the year dummies represent the average change in the dependent variable (conditional on covariates $X_{i j t}$ ) between year $t$ and year $t-1$. For instance, consider the model in which the dependent variable is an indicator for whether the student applied to an eligible school in Maryland or Virginia. If the DCTAG program had a positive impact on the likelihood that a student applied to a DCTAG-eligible college in Maryland or Virginia, we would expect to see

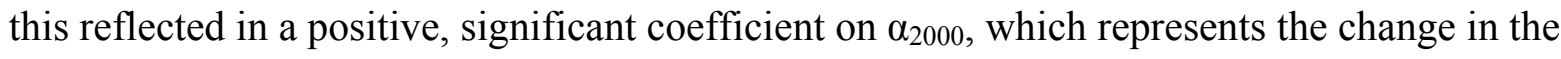


probability that a DC student applied to an eligible college in Maryland or Virginia between 1999 and 2000, the first year that the program was available. With lags in response to the introduction of the program, we might also expect a positive, significant coefficient on $\alpha_{2001}$, which represents any change in the same probability between 2000 and 2001 .

It is of course possible that factors other than the DCTAG program were driving changes in the college application decisions of DC residents over this period. To control for such potentially confounding factors, we use students from nearby large cities as a control group and estimate a model for the full sample that interacts the year dummies with an indicator for whether the student is a resident of DC or some other city:

$$
Y_{i j t}=\gamma_{o}+X_{i j t} \gamma_{1}+\sum_{t=1995}^{2001} \alpha_{t} \delta_{t}+\sum_{j} \mu_{j} \phi_{j}+\sum_{t=1995}^{2001}\left(\alpha_{t} \times D C\right) \theta_{t}+v_{i j t}
$$

In this model, $Y_{i j t}$ is the outcome variable of interest for student $i$ in city $j$ graduating from high school in year $t$. As above, $X_{i j t}$ is a vector of individual-level characteristics, $\alpha_{t}$ represents a set of year dummies, defined as described above, $\mu_{j}$ represents a set of city dummy variables, $D C$ is a dummy variable equal to one if the city is DC, zero otherwise, and $v_{i j t}$ is a stochastic error term. In this model, the coefficient on the interaction between $\alpha_{\mathrm{t}}$ and $D C$ represents the change in the dependent variable from year $t-1$ to year $t$ in DC relative to the control cities. If DCTAG had a positive impact on the likelihood that a student applied to a DCTAG-eligible college in Maryland or Virginia, we would expect to see this reflected in positive, significant coefficients on $\alpha_{2000} \times D C$ and/or $\alpha_{2001} \times D C$. These two coefficients represent the change in the probability that a DC student applied to an eligible college in Maryland or Virginia between 1999 and 2000 and between 2000 and 2001, over and above any change in the probabilities for students in the control cities. 


\section{B. IPEDS Dataset}

To examine actual college enrollments of students from DC and surrounding states, we use data from the Integrated Postsecondary Education Data System (IPEDS), a dataset maintained by the National Center for Education Statistics of the U.S. Department of Education. The IPEDS contains data on institutions that grant baccalaureate or higher degrees, institutions that award two-year degrees, and less-than-two-year institutions. The IPEDS database consists of institution-level data collected through a set of annual surveys that together provide information on a range of items, including tuition and fall enrollments. In our analysis, we use institution-level IPEDS data for two- and four-year institutions from 1996, 1998 and 2000 on fall enrollments of freshmen by state of residence and in- and out-of-state tuition rates.

\section{The Effects of DCTAG on College Application and Enrollment Decisions}

\section{A. DCTAG's Effect on Applications to Four-Year Colleges}

One important objective of the DCTAG program is to encourage DC residents who would not otherwise have done so to apply to a four-year college or university. Ideally, we would like to examine whether the share of DC high school graduates sending SAT scores to a four-year college increased after the program was implemented. The total number of DC residents sending SAT scores to a four-year college did indeed increase, from 1,394 in 1999 to 1,540 in 2001 (see Table 1, column 1). But it is difficult to determine whether the share of DC students sending scores to four-year institutions increased, as there are no reliable estimates of the total number of DC residents graduating from high school in each year. Private schools account for a significant proportion of the high school graduates in the DC metropolitan area, but the available data on private high school graduates are collected from the schools, and reporting 
by state is based on the schools' locations rather than the student's state of residence. Many of the students who attend private high schools located in the District, however, are residents of Maryland or Virginia, and conversely, some DC residents attend private high schools located outside of the District's boundaries in the Maryland and Virginia suburbs. ${ }^{7}$ There is thus no obvious way to determine the number of DC residents graduating from private high schools each year.

In contrast, almost all of the students who graduate from the District's public high schools are DC residents, and data on the number of public high school graduates are readily available. Although the demographics of the public school population differ in some important ways from those of the full population of DC high school graduates, the population of public high school students is of interest in its own right, so it is useful to examine both the number and share of DC's public high school graduates applying to a four-year college or university. ${ }^{8}$ Overall, in each year from 1994 through 2001, roughly two-thirds of SAT-takers living in DC attended public high schools. The number of DC public high school graduates taking the SAT increased considerably after the implementation of DCTAG, from 957 in 1999 to 1,084 in 2001 (column 2). Although the number of students graduating from the District's public high schools also has increased over this period (column 3), the share of District public high school graduates

\footnotetext{
${ }^{7}$ While data on both residence and school location are not available for the full population of DC students, tabulations from the SAT database can provide a general sense of high school enrollment patterns among SAT-takers. Only 72 percent of SAT-takers who live in DC and attend a private high school attend a school located in the District, with 22 percent attending a Maryland high school and 5 percent a Virginia high school. Of the SAT-takers enrolled in private high schools located in the District, 40 percent are District residents, 42 percent are Maryland residents, and 18 percent are Virginia residents. In contrast, 98 percent of SAT-takers who live in DC and attend a public high school attend a school located in the District, and 97 percent of those attending a DC public high school are District residents. ${ }^{8}$ In 2000, the most recent year for which the Department of Education has published data on student characteristics, 2,695 students graduated from the DC public high schools and 1,231 students graduated from private high schools located in the District. Less than 4 percent of the graduates of the DC public high schools were white, non-Hispanic, a share that is far below the share of white, non-Hispanics in the DC population of high school age. Throughout this analysis, we categorize public high school graduates separately from charter school graduates.
} 
who took the SAT and had their scores sent to at least one four-year college increased substantially in 2000 and remained high in 2001 (column 4). This pattern is quite different from that for our comparison cities, in which the share of public high school graduates taking the SAT has declined since 1998. ${ }^{9}$ This suggests that the DCTAG program encouraged students who might not otherwise have done so to apply to a four-year college.

The DCTAG program also may have affected the types of four-year colleges to which DC residents apply, as it makes public colleges and universities located in other jurisdictions considerably more affordable. ${ }^{10}$ Table 2 presents the results of regression model (1) in order to examine whether the proportion of DC SAT-takers sending scores to eligible institutions in Maryland or Virginia (columns 1 and 2) or in any state (columns 3 and 4) increased after the program was implemented. In each of these models, the year dummy variable coefficients capture the change from one year to the next in the probability that a graduating DC high school senior who has taken the SAT sends his or her scores to at least one Maryland or Virginia public four-year school or to at least one public four-year school located in any state. The models reported in columns (1) and (3) contain only the year dummy variables; those in columns (2) and (4) control for demographic covariates that may be correlated with students' college application decisions, including the type of high school a student attends (public, private, or other, where "other" includes charter schools and home schools, and represents less than 1 percent of the

\footnotetext{
${ }^{9}$ The number of high school graduates is based on district-level reports contained in the National Center for Education Statistics' Common Core of Data. City and school district boundaries coincide for each of the cities used in the analysis.

${ }^{10}$ As already noted, the DCTAG program also offers a $\$ 2,500$ subsidy to students who attend selected private colleges and universities. Most of these colleges and universities - particularly those that are included because they are located in the DC metropolitan area, rather than because they are historically black institutions - are quite expensive, and the DCTAG subsidy is unlikely to make them affordable for someone who would have been deterred by their high tuitions in the first place.
} 
sample), the student's race/ethnicity, the level of education obtained by the student's parents and the student's combined math and verbal SAT score.

In 1999, 47.8 percent of DC SAT-takers sent their scores to at least one public Maryland or Virginia school, and 73.5 percent sent their scores to at least one public institution somewhere in the country. The Table 2 models without controls for demographic characteristics suggest that the share of DC SAT-takers who sent their scores to at least one Maryland or Virginia school rose by 9.1 percentage points in 2000 and an additional 6.4 percentage points in 2001 . The cumulative increase in the share sending their scores to any public institution was somewhat smaller - 7.2 percentage points in 2000 plus an additional 6.7 percentage points in 2001. Adding controls for demographic characteristics has only a small effect on the coefficients of interest.

Of course, external factors other than the introduction of the DCTAG program might account for the increase in the share of SAT-takers who apply to at least one out-of-own-state public four-year college. In order to control for potentially confounding trends in college application behavior, in Table 3 we present results from difference-in-differences model (2), using students from Baltimore, Newark, Norfolk, and Philadelphia as a control group. The year dummy variable coefficients in these models capture the effects of any general influence on the propensity to apply to out-of-state public institutions. The coefficients on the interactions between the year dummies and the DC dummy represent the effects of anything that is DCspecific - most notably the DCTAG program — on District students' application patterns. The coefficients on these interaction variables - both in the models without demographic controls and in the models to which those controls have been added — differ only modestly from the year dummy coefficients in the simpler models reported in Table 3 and also indicate significant 
increases in the likelihood that a DC resident who took the SAT sent scores to a DCTAG-eligible institution either in Maryland or Virginia or anywhere in the country in both 2000 and $2001 .^{11}$

An important concern for education policymakers is how tuition subsidy and financial aid policies will differentially affect students from different socioeconomic backgrounds. In Table 4 we present results from regression model (2) separately for various subgroups. For ease of interpretation, we present only the coefficients on the DC $x$ year interactions, which show the change in college application behavior of DC residents relative to their peers in the control cities and conditional on the demographic characteristics described above.

We begin by examining the program's effects on public versus private high school graduates. For students in the District of Columbia, whether a student attends a public or a private high school is highly correlated with family socioeconomic status. Many DC residents who graduate from private high schools expect to attend prestigious private colleges but might also consider selected public universities. Interestingly, these students (or their parents) do appear to be price sensitive, at least with respect to the set of schools to which they apply. Over the two-year period from 1999 to 2001, the share of college-bound DC private high school graduates who sent their test scores to at least one Maryland or Virginia public college rose 19.5 percentage points, controlling for other factors that might affect college applications. The increase for college-bound DC public high school graduates was somewhat smaller, just 12.7 percentage points. The gap was even bigger with regard to the share sending at least one

\footnotetext{
${ }^{11}$ In both cases, the dependent variable is defined as 1 if the student applied to an out-of-own-state DCTAG-eligible institution in Maryland or Virginia, or nationwide, and zero otherwise. The former is equal to 1 for Maryland residents only if they applied to an eligible institution in Virginia, and for Virginia residents only if they applied to an eligible institution in Maryland. We obtain results that are both qualitatively and quantitatively similar when Maryland and Virginia residents are excluded from the calculations. Results are similar in a simpler difference-in-differences model that includes a single dummy variable for post-DCTAG in place of the year dummies, and a $D C \times$ post-DCTAG interaction variable in place of the year $\times D C$ interactions.
} 
application to any public university nationwide: a 20.9 percentage point increase for the private high school graduates, as compared to an 8.8 percentage point increase for the public high school graduates. Of course, these results do not necessarily establish that DCTAG had a smaller overall effect on public high school students, since the SAT data reflect only students' applications to four-year colleges, whereas DCTAG assistance may help with the costs of attending either a two-year or a four-year school.

A similar pattern emerges for white graduates as compared to black graduates. The coefficients shown in columns (5) and (7) imply that, holding other factors constant, the share of college-bound white graduates applying to any Maryland or Virginia public college rose by 20.2 percentage points between 1999 and 2001, as compared to 14.2 percentage points for black graduates. And the coefficients in columns (6) and (8) imply that, again holding other factors constant, the share of white graduates applying to any public college nationwide rose by 23.2 percentage points, as compared to 10.3 percentage points for blacks.

The program also appears to have a differential effect on students according to the educational attainment of their parents. Holding other factors constant, among SAT-takers with a parent who attended college, the share sending their scores to at least one Maryland or Virginia public college rose by 17.6 percentage points between 1999 and 2001, as compared to 8.1 percentage points for those whose parents completed no education beyond high school. The comparable figures for applications to any public college nationwide are similar: an increase of 14.9 percentage points for those who had at least one parent who attended college, as compared to an increase of 4.5 percentage points for those parents never went beyond high school.

Interestingly, differences between DC high school graduates with above-average and below-average SAT scores are less marked. In the college-bound group with combined math 
and verbal scores above 1000, the share who sent at least one application to a public Maryland or Virginia school rose 17.1 percentage points between 1999 and 2001, as compared to an increase of 13.8 percentage points among those with combined scores of 1000 or less. Similarly, the share applying to at least one public college nationwide rose 16.6 percentage points among those with combined scores above 1000, as compared to 9.6 percentage points among those with lower combined scores.

An alternative to looking at whether a student applies to at least one public institution, as we have in the previous models, is to look at how many and what share of a student's applications go to such institutions. This information is shown in Table 5, in which we present results of regression model (2) with number of scores (columns 1-3) or share of scores (columns 4 and 5) each individual sent to various types of institutions as the dependent variable. All models include city-of-residence dummies and demographic covariates; as in Table 4, we present only the coefficients on the DC $\mathrm{x}$ year interactions. As shown in column (1), while the average number of Maryland or Virginia DCTAG-eligible institutions to which DC residents sent scores has been somewhat variable over the years relative to the control group, the greatest increase in the number of these institutions to which DC residents sent scores occurred in the years following DCTAG's implementation. Between 1999 and 2001, the average number of scores DC residents sent to these schools increased by 0.41 , all else equal. The average number of DCTAG-eligible schools to which DC residents sent scores increased by 0.64 between 1999 and 2001, as shown in column (2). The average number of four-year institutions to which DC residents sent scores (column 3) also increased, by 0.25 between 1999 and 2001. Columns (5) and (6) indicate that the average fraction of scores DC residents sent to eligible institutions increased between 1999 and 2001. Taken together, these results suggest that DCTAG induced 
some DC residents to apply to more institutions than they would have in the absence of the program and also shifted the composition of the institutions to which DC residents were applying towards those eligible for the DCTAG program.

\section{B. DCTAG's Effect on College Enrollment}

One of the ultimate goals of the DCTAG program is to increase college enrollments of DC residents. All of the data we have examined thus far relate to the decision to apply to a (four-year) college or university, proxied for by the decision to send SAT scores. In this section we examine data on college enrollments from the IPEDS database. In particular, we focus on the number of DC residents who graduated from high school in the previous twelve months who are enrolled as first-time college freshmen in fall 1996, fall 1998 or fall $2000 .^{12}$ The IPEDS data provide an important complement to the SAT data, as they allow us to examine where DC residents actually choose to enroll after the introduction of DCTAG, including enrollments at both two- and four-year colleges.

Tabulations based on the IPEDS data are reported in Table 6. We report enrollments for 1996, 1998, and 2000 for the 15 schools that had the largest increases in enrollment of DC residents and the 15 schools that had the largest declines in enrollment of DC residents between 1998 and 2000. The two schools that appear to have benefited most from the introduction of the DCTAG program are Virginia State University, which saw its enrollment of DC freshmen jump by 92 students between 1998 and 2000, and Norfolk State University, which experienced an enrollment increase of 48 students. Both are historically black public institutions that appear previously to have enrolled relatively few students from the District of Columbia. Overall, 12 of

\footnotetext{
${ }^{12}$ The IPEDS has information on both total freshmen enrollment and enrollment of freshmen who graduated from high school in the past twelve months. We focus on the latter, as at least initially, only recent high school graduates were eligible for the DCTAG program.
} 
the 15 colleges and universities that increased their enrollment of DC freshmen by 9 or more students between 1998 and 2000 were DCTAG-eligible institutions.

While some schools appear to have gained significantly from the introduction of the DCTAG program, others appear to have lost. Five of the fifteen schools with the greatest declines in enrollment of DC residents are located in the District, suggesting that to some extent DC residents who would otherwise have attended college there instead opted to use the DCTAG assistance to attend schools outside the District. Enrollments of DC freshmen declined by 15 students at the University of the District of Columbia (UDC), the District's only public university, following the introduction of the DCTAG program. ${ }^{13}$ Enrollments of DC freshmen also dropped at a number of Washington-area private schools at which students were eligible for the smaller \$2,500 tuition break provided under the DCTAG program, including Georgetown University (enrollment of DC residents down by 8 students), George Washington University (37 students), and Howard University (57 students). At the latter two schools, the enrollment declines appear to be the continuation of a trend begun prior to the introduction of DCTAG. It seems clear that the size of the tuition break offered to students enrolling at these institutions was not large enough to have a significant positive effect on their attendance decisions, at least not relative to the larger tuition break available to students attending nearby public universities.

In total, college enrollments of DC residents who graduated from high school in the previous twelve months increased enormously between 1998 and 2000 at DCTAG-eligible institutions in Maryland and Virginia, jumping by 292 students, an increase of 164 percent from the 1998 base of 178 students. Enrollments of DC freshmen at all DCTAG-eligible institutions

\footnotetext{
${ }^{13}$ The UDC data on enrollment of recent high school graduates as freshmen contained in the IPEDS were obviously in error (decreasing from 1,440 in 1994 to 568 in 1996 to 229 in 1998 to 217 in 2000). Rather than using these data, we instead report corrected data that we obtained directly from UDC's Office of University Statistics.
} 
(including those in Maryland and Virginia) rose by less, a total of 231 students, suggesting that some of the increase at Maryland and Virginia schools was siphoned away from public institutions in other states. This is as we might expect, given that at the time most students planning to enter college in fall of 2000 were applying to schools, only public institutions in Maryland and Virginia were known to be eligible for the subsidy.

The program also seems to have successfully met its goal of increasing overall enrollments of DC freshmen, rather than simply shifting students from non-eligible to eligible schools. Overall enrollments of DC freshmen graduating from high school in the previous twelve months increased by 118 students, or 6.6 percent, between 1998 and 2000. This increase is about 12 percent of the approximately 950 students coming directly from high school who used the grant in its first year (U.S.General Accounting Office, 2002). Although we do not have a precise estimate of the total number of DC high school graduates in those years, data from Table 1 indicate that the number of public high school graduates declined from 2,777 to 2,695 between 1998 and 2000. Assuming that the number of private high school graduates remained roughly constant over this period, our estimates from the IPEDS data suggest that an increasing number of DC residents were enrolling in college, even while the number of high school graduates was declining.

Table 7 displays in-state and out-of-state 1998 tuition charges at the 15 schools with the largest freshmen enrollment increases, and the 15 with the largest freshmen enrollment declines, of DC residents. The differences between out-of-state and in-state tuitions at the eligible schools experiencing the largest increases in DC enrollments were substantial, ranging from $\$ 1,692$ at Montgomery College of Rockville to $\$ 12,482$ at University of Colorado at Boulder. Taking a simple average of these tuition differences across all eligible public colleges and universities, 
with an adjustment to account for the annual benefit cap of $\$ 10,000$, the average potential tuition savings available to a DCTAG recipient attending an eligible Maryland or Virginia school was $\$ 3,845$; the average potential savings was $\$ 3,426$ for those attending any DCTAG-eligible school nationwide.

C. Comparison with Other Estimates of the Effect of College Price on Enrollment

For comparison with the literature, it is useful to calculate the effect on the college attendance rate of $\$ 1,000$ of aid. For instance, Dynarski (2000) estimates that $\$ 1,000$ under the Georgia HOPE Scholarship program increased the college attendance rate at eligible schools in Georgia by about 4 percentage points. If we assume that the number of 17-year olds residing in DC remained roughly constant between 1998 and 2000 at 5,860 (as tabulated from the 2000 Census), then total freshmen enrollment of DC residents increased by $118 / 5,860=2.0$ percentage points between 1998 and 2000. (This estimate is somewhat conservative - the decline in the number of public high school graduates suggests that the number of 17 -year olds actually may have fallen over the period.) If we suppose that DC residents might consider attending any school in the country, their average potential tuition savings under the DCTAG program was $\$ 1,755 .{ }^{14}$ We can then roughly calculate that total college attendance of DC residents increased by 1.1 percentage points for each $\$ 1,000$ of tuition assistance.

This estimate, although rough, is at the low end of estimates in the literature, which range from 1.2 percentage points to 9.2 percentage points per $\$ 1000$ of aid. Because the IPEDS data are available only through the fall of 2000 , however, we may not be observing the full long-term

\footnotetext{
${ }^{14}$ As displayed in Table 7, the average difference between out-of-state and in-state tuition across all schools represented in the IPEDS tuition survey, including both schools eligible for the DCTAG subsidy and schools that are not eligible, is $\$ 1,765$. In calculating the average value of the subsidy, however, we must account for the fact that the DCTAG benefit is capped at $\$ 10,000$ per year, which implies an average tuition savings of $\$ 1,755$.
} 
effects of the DCTAG program. Over the next few years, as current program participants' experiences with the program are shared with friends and relatives, it may gain in popularity and its effects on college enrollments may grow. Indeed, our analysis of college applications suggests that applications to eligible schools continued to increase between 2000 and 2001.

\section{Conclusions}

The DCTAG program provides a unique opportunity to study the effects of a large, exogenous change in tuition price on students' college decisions. We examine the program's effects on students' decisions about where to apply to college and where to enroll. We find that students were cost-sensitive in both their application and enrollment decisions. The introduction of the DCTAG program was accompanied by an increase in the share of DC public high school graduates taking the SAT even while the share of public high school graduates in a set of comparison cities taking the SAT was declining. Although we are not able to calculate the share of private high school graduates taking the SAT, the number of private high school graduates taking the SAT increased over this period as well.

Among DC high school graduates who took the SAT, the share sending their scores to at least one public college or university rose significantly, as did the share of all test scores sent out by DC high school graduates going to such schools. We interpret this as strong evidence that the DCTAG program affected college application patterns. We also find that the DCTAG program had a considerably larger effect on the propensity to apply to an eligible four-year college for

students from more advantaged backgrounds - for students attending a private high school than for those attending a public one, for white students than for black students, for students with a 
parent that attended college than for those whose parents did not, and (to a lesser degree) for students scoring higher on the SAT than for those scoring lower on the exam.

The IPEDS data provide evidence that the program had an impact, not only on applications, but also on the pattern of college enrollments among DC residents. Freshmen enrollments of DC residents at eligible Maryland and Virginia schools increased by 164 percent between 1998 and 2000, and by 47 percent at eligible schools throughout the country. Total enrollments increased by a more moderate 6.6 percent, suggesting that the program had a weaker effect on whether a student decided to attend college than on where they decided to attend. Overall, the percentage of DC residents of high -school-graduation age enrolled as freshmen increased by only 2 percentage points, or 1.14 percentage points for every $\$ 1,000$ of aid, between 1998 and 2000, the first year the subsidy was available. Data from subsequent years may reveal a larger effect on enrollments, as students continue to learn about and apply for the DCTAG program. 


\section{References}

Card, David and Alan B. Krueger. 2003. "Would the Elimation of Affirmative Action Affect Highly-Qualified Minority Applicants? Evidence from California and Texas." Mimeo, Princeton University, Princeton, New Jersey.

Clark, Melissa A. 2003. "Selection Bias in College Admissions Test Data." Mimeo, Princeton University, Princeton, New Jersey.

Dynarski, Susan. 2000. "Hope for Whom? Financial Aid for the Middle Class and Its Impact on College Attendance." National Tax Journal 53(3): 629-662.

Dynarski, Susan. 2002. "The Behavioral and Distributional Implications of Aid for College." American Economic Review 92(2): 279-285.

Dynarski, Susan. 2003. "Does Aid Matter? Measuring the Effect of Student Aid on College Attendance and Completion." American Economic Review 93(1): 279-288.

Kane, Thomas J. 1994. "College Attendance by Blacks Since 1970: The Role of College Cost, Family Background, and the Returns to Education." Journal of Political Economy 102(5): 878-911.

Kane, Thomas J. 2003. "A Quasi-Experimental Estimate of the Impact of Financial Aid on College-Going.” NBER Working Paper \# 9703.

Leslie, Larry and Paul Brinkman. The Economic Value of Higher Education. New York: Macmillan, 1988.

Linsenmeier, David M., Harvey S. Rosen, and Cecilia Elena Rouse. 2002. "Financial Aid Packages and College Enrollment Decisions: An Econometric Case Study.” NBER Working Paper \#9228.

U.S. Census Bureau. 2001. County and City Data Book: 2000. Washington, DC: U.S. Government Printing Office.

U.S. General Accounting Office. 2002. DC Tuition Assistance Grants: Program May Increase College Choices, but a Few Program Procedures May Hinder Grant Receipt for Some Residents. United States General Accounting Office: Washington, DC.

Van der Klaauw, Wilbert. 2002. "Estimating the Effect of Financial Aid Offers on College Enrollment: A Regression-Discontinuity Approach." International Economic Review 43(4): 1249-1287. 
Table 1

Number of SAT Takers as Compared to Number of High School Graduates

\begin{tabular}{|c|c|c|c|c|c|c|c|c|}
\hline & \multicolumn{4}{|c|}{ District of Columbia } & \multicolumn{4}{|c|}{ Comparison Cities } \\
\hline & \multirow{2}{*}{$\begin{array}{c}\begin{array}{c}\text { All High } \\
\text { Schools }\end{array} \\
\text { SAT Takers } \\
\text { (1) }\end{array}$} & \multicolumn{3}{|c|}{ Public High Schools } & \multirow{2}{*}{$\begin{array}{c}\begin{array}{c}\text { All High } \\
\text { Schools }\end{array} \\
\text { SAT Takers } \\
\text { (5) }\end{array}$} & \multicolumn{3}{|c|}{ Public High Schools } \\
\hline & & $\begin{array}{c}\text { SAT Takers } \\
\text { (2) }\end{array}$ & $\begin{array}{l}\text { Graduates } \\
\text { (3) }\end{array}$ & $\begin{array}{c}\text { Ratio } \\
(4)\end{array}$ & & $\begin{array}{c}\text { SAT Takers } \\
\text { (6) }\end{array}$ & $\begin{array}{c}\text { Graduates } \\
(7)\end{array}$ & $\begin{array}{c}\text { Ratio } \\
(8)\end{array}$ \\
\hline 1994 & 1,481 & 992 & 3,207 & 0.309 & 9,974 & 6,086 & -- & -- \\
\hline 1995 & 1,520 & 1,060 & 2,974 & 0.356 & 9,993 & 6,263 & -- & -- \\
\hline 1996 & 1,448 & 979 & 2,696 & 0.363 & 10,350 & 6,493 & -- & -- \\
\hline 1997 & 1,451 & 990 & 2,853 & 0.347 & 10,437 & 6,561 & -- & -- \\
\hline 1998 & 1,481 & 1,011 & 2,777 & 0.364 & 10,805 & 6,833 & 15,702 & 0.435 \\
\hline 1999 & 1,394 & 957 & 2,675 & 0.358 & 10,348 & 6,583 & 16,365 & 0.402 \\
\hline 2000 & 1,543 & 1,075 & 2,695 & 0.399 & 9,831 & 6,145 & 16,546 & 0.371 \\
\hline 2001 & 1,540 & 1,084 & 2,808 & 0.386 & 9,917 & 6,292 & 16,695 & 0.377 \\
\hline
\end{tabular}

Source: National Center for Education Statistics Common Core of Data, various years, and SAT Score Database.

Notes: Number of SAT takers is an actual number for DC and a weighted estimate for the comparison cities (Baltimore, Newark, Norfolk, and Philadelphia). Number of public high school graduates is based on district-level data from the Common Core of Data as reported by public school districts in the relevant cities. Each city contains only one regular public school district. Data on high school graduates from comparison cities are not available for 1994-1997. 
Table 2

Determinants of Whether Students' SAT Scores Sent to at Least One Out-of-State Public 4-Year College or University; DC Sample Only

\begin{tabular}{|c|c|c|c|c|}
\hline & \multicolumn{2}{|c|}{ MD or VA School } & \multicolumn{2}{|c|}{ School in Any State } \\
\hline & $(1)$ & $(2)$ & (3) & $(4)$ \\
\hline Constant & $\begin{array}{c}0.523 \\
(0.013)\end{array}$ & $\begin{array}{c}0.612 \\
(0.031)\end{array}$ & $\begin{array}{c}0.777 \\
(0.011)\end{array}$ & $\begin{array}{c}0.784 \\
(0.028)\end{array}$ \\
\hline Change 1994-95 & $\begin{array}{c}-0.041 \\
(0.018)\end{array}$ & $\begin{array}{c}-0.038 \\
(0.018)\end{array}$ & $\begin{array}{c}-0.003 \\
(0.015)\end{array}$ & $\begin{array}{c}-0.001 \\
(0.015)\end{array}$ \\
\hline Change 1995-96 & $\begin{array}{c}0.005 \\
(0.018)\end{array}$ & $\begin{array}{c}0.011 \\
(0.018)\end{array}$ & $\begin{array}{l}-0.017 \\
(0.016)\end{array}$ & $\begin{array}{l}-0.013 \\
(0.015)\end{array}$ \\
\hline Change 1996-97 & $\begin{array}{l}-0.000 \\
(0.019)\end{array}$ & $\begin{array}{c}0.000 \\
(0.018)\end{array}$ & $\begin{array}{c}-0.004 \\
(0.016)\end{array}$ & $\begin{array}{c}-0.002 \\
(0.015)\end{array}$ \\
\hline Change 1997-98 & $\begin{array}{c}0.035 \\
(0.018)\end{array}$ & $\begin{array}{c}0.024 \\
(0.018)\end{array}$ & $\begin{array}{c}0.024 \\
(0.016)\end{array}$ & $\begin{array}{c}0.016 \\
(0.015)\end{array}$ \\
\hline Change 1998-99 & $\begin{array}{c}-0.045 \\
(0.019)\end{array}$ & $\begin{array}{c}-0.046 \\
(0.018)\end{array}$ & $\begin{array}{c}-0.042 \\
(0.016)\end{array}$ & $\begin{array}{c}-0.041 \\
(0.015)\end{array}$ \\
\hline Change 1999-2000 & $\begin{array}{c}0.091 \\
(0.018)\end{array}$ & $\begin{array}{c}0.090 \\
(0.018)\end{array}$ & $\begin{array}{c}0.072 \\
(0.016)\end{array}$ & $\begin{array}{c}0.072 \\
(0.015)\end{array}$ \\
\hline Change 2000-2001 & $\begin{array}{c}0.064 \\
(0.018)\end{array}$ & $\begin{array}{c}0.058 \\
(0.017)\end{array}$ & $\begin{array}{c}0.067 \\
(0.013)\end{array}$ & $\begin{array}{c}0.061 \\
(0.013)\end{array}$ \\
\hline Black (yes = 1) & & $\begin{array}{c}0.176 \\
(0.015)\end{array}$ & & $\begin{array}{c}0.170 \\
(0.015)\end{array}$ \\
\hline Hispanic (yes $=1$ ) & & $\begin{array}{c}0.084 \\
(0.025)\end{array}$ & & $\begin{array}{c}-0.017 \\
(0.024)\end{array}$ \\
\hline Other race $($ yes $=1$ ) & & $\begin{array}{c}0.140 \\
(0.020)\end{array}$ & & $\begin{array}{c}0.093 \\
(0.019)\end{array}$ \\
\hline Parents college (yes = 1) & & $\begin{array}{c}-0.036 \\
(0.011)\end{array}$ & & $\begin{array}{c}0.003 \\
(0.008)\end{array}$ \\
\hline Private high school (yes $=1$ ) & & $\begin{array}{l}-0.021 \\
(0.012)\end{array}$ & & $\begin{array}{c}-0.042 \\
(0.010)\end{array}$ \\
\hline Other high school (yes = 1) & & $\begin{array}{c}-0.021 \\
(0.045)\end{array}$ & & $\begin{array}{c}-0.056 \\
(0.034)\end{array}$ \\
\hline SAT V+M Score/100 & & $\begin{array}{c}-0.022 \\
(0.002)\end{array}$ & & $\begin{array}{c}-0.014 \\
(0.002)\end{array}$ \\
\hline Observations & 11,858 & 11,858 & 11,858 & 11,858 \\
\hline R-squared & 0.01 & 0.07 & 0.01 & 0.08 \\
\hline
\end{tabular}

Source: SAT Score Database.

Notes: All models weighted OLS regressions with heteroskedasticity-consistent standard errors. 
Table 3

Determinants of Whether Students' SAT Scores Sent to at Least

One Out-of-State Public 4-Year College or University; Difference-in-Difference Model

\begin{tabular}{|c|c|c|c|c|}
\hline & MD or & School & School i & ny State \\
\hline & $(1)$ & $(2)$ & (3) & (4) \\
\hline Constant & $\begin{array}{c}0.523 \\
(0.013)\end{array}$ & $\begin{array}{c}0.285 \\
(0.015)\end{array}$ & $\begin{array}{c}0.777 \\
(0.011)\end{array}$ & $\begin{array}{c}0.369 \\
(0.017)\end{array}$ \\
\hline Change 1994-95 & $\begin{array}{c}-0.019 \\
(0.007)\end{array}$ & $\begin{array}{l}-0.019 \\
(0.006)\end{array}$ & $\begin{array}{c}0.004 \\
(0.010)\end{array}$ & $\begin{array}{c}0.004 \\
(0.010)\end{array}$ \\
\hline Change 1995-96 & $\begin{array}{c}0.020 \\
(0.007)\end{array}$ & $\begin{array}{c}0.020 \\
(0.007)\end{array}$ & $\begin{array}{c}0.012 \\
(0.010)\end{array}$ & $\begin{array}{c}0.011 \\
(0.010)\end{array}$ \\
\hline Change 1996-97 & $\begin{array}{l}-0.008 \\
(0.007)\end{array}$ & $\begin{array}{l}-0.009 \\
(0.007)\end{array}$ & $\begin{array}{l}-0.016 \\
(0.010)\end{array}$ & $\begin{array}{l}-0.018 \\
(0.010)\end{array}$ \\
\hline Change 1997-98 & $\begin{array}{l}-0.005 \\
(0.007)\end{array}$ & $\begin{array}{l}-0.003 \\
(0.006)\end{array}$ & $\begin{array}{c}0.010 \\
(0.010)\end{array}$ & $\begin{array}{c}0.014 \\
(0.010)\end{array}$ \\
\hline Change 1998-99 & $\begin{array}{l}-0.008 \\
(0.007)\end{array}$ & $\begin{array}{l}-0.010 \\
(0.007)\end{array}$ & $\begin{array}{l}-0.025 \\
(0.010)\end{array}$ & $\begin{array}{l}-0.027 \\
(0.010)\end{array}$ \\
\hline Change 1999-2000 & $\begin{array}{l}-0.001 \\
(0.007)\end{array}$ & $\begin{array}{l}-0.002 \\
(0.007)\end{array}$ & $\begin{array}{c}0.012 \\
(0.010)\end{array}$ & $\begin{array}{c}0.010 \\
(0.010)\end{array}$ \\
\hline Change 2000-2001 & $\begin{array}{c}0.008 \\
(0.007)\end{array}$ & $\begin{array}{c}0.005 \\
(0.007)\end{array}$ & $\begin{array}{c}0.012 \\
(0.010)\end{array}$ & $\begin{array}{c}0.007 \\
(0.010)\end{array}$ \\
\hline DC*Change 1994-95 & $\begin{array}{l}-0.022 \\
(0.019)\end{array}$ & $\begin{array}{l}-0.020 \\
(0.019)\end{array}$ & $\begin{array}{l}-0.007 \\
(0.018)\end{array}$ & $\begin{array}{l}-0.005 \\
(0.018)\end{array}$ \\
\hline DC*Change 1995-96 & $\begin{array}{l}-0.014 \\
(0.020)\end{array}$ & $\begin{array}{l}-0.016 \\
(0.019)\end{array}$ & $\begin{array}{l}-0.029 \\
(0.019)\end{array}$ & $\begin{array}{l}-0.031 \\
(0.019)\end{array}$ \\
\hline DC*Change 1996-97 & $\begin{array}{c}0.007 \\
(0.020)\end{array}$ & $\begin{array}{c}0.011 \\
(0.020)\end{array}$ & $\begin{array}{c}0.012 \\
(0.019)\end{array}$ & $\begin{array}{c}0.018 \\
(0.019)\end{array}$ \\
\hline DC*Change 1997-98 & $\begin{array}{c}0.041 \\
(0.020)\end{array}$ & $\begin{array}{c}0.039 \\
(0.020)\end{array}$ & $\begin{array}{c}0.014 \\
(0.019)\end{array}$ & $\begin{array}{c}0.013 \\
(0.019)\end{array}$ \\
\hline DC*Change 1998-99 & $\begin{array}{l}-0.037 \\
(0.020)\end{array}$ & $\begin{array}{l}-0.036 \\
(0.020)\end{array}$ & $\begin{array}{l}-0.017 \\
(0.019)\end{array}$ & $\begin{array}{l}-0.016 \\
(0.019)\end{array}$ \\
\hline DC*Change 1999-2000 & $\begin{array}{c}0.092 \\
(0.020)\end{array}$ & $\begin{array}{c}0.097 \\
(0.020)\end{array}$ & $\begin{array}{c}0.060 \\
(0.019)\end{array}$ & $\begin{array}{c}0.068 \\
(0.019)\end{array}$ \\
\hline DC*Change 2000-2001 & $\begin{array}{c}0.056 \\
(0.019)\end{array}$ & $\begin{array}{c}0.057 \\
(0.019)\end{array}$ & $\begin{array}{c}0.055 \\
(0.017)\end{array}$ & $\begin{array}{c}0.057 \\
(0.017)\end{array}$ \\
\hline State dummies & yes & yes & yes & yes \\
\hline Demographic covariates & no & yes & no & yes \\
\hline $\begin{array}{l}\text { Observations } \\
\text { R-squared }\end{array}$ & $\begin{array}{c}62,415 \\
0.13\end{array}$ & $\begin{array}{c}62,415 \\
0.15\end{array}$ & $\begin{array}{c}62,415 \\
0.09\end{array}$ & $\begin{array}{c}62,415 \\
0.14\end{array}$ \\
\hline
\end{tabular}

Source: SAT Score Database.

Notes: All models weighted OLS regressions with heteroskedasticity-consistent standard errors. 
Table 4

Determinants of Whether Students' SAT Scores Sent to at Least One

Out-of-State Public 4-Year College or University; Difference-in-Difference Models, Selected Subgroups

\begin{tabular}{|c|c|c|c|c|c|c|c|c|}
\hline & \multicolumn{4}{|c|}{ Type of High School Attended } & \multicolumn{4}{|c|}{ Race } \\
\hline & \multicolumn{2}{|c|}{ Public } & \multicolumn{2}{|c|}{ Private } & \multicolumn{2}{|c|}{ White } & \multicolumn{2}{|c|}{ Black } \\
\hline & $\begin{array}{c}\mathrm{MD} / \mathrm{VA} \\
(1)\end{array}$ & $\begin{array}{c}\text { Any } \\
(2)\end{array}$ & $\begin{array}{c}\mathrm{MD} / \mathrm{VA} \\
\text { (3) }\end{array}$ & $\begin{array}{c}\text { Any } \\
(4)\end{array}$ & $\begin{array}{c}\mathrm{MD} / \mathrm{VA} \\
(5)\end{array}$ & $\begin{array}{c}\text { Any } \\
(6)\end{array}$ & $\begin{array}{c}\mathrm{MD} / \mathrm{VA} \\
(7)\end{array}$ & $\begin{array}{c}\text { Any } \\
(8)\end{array}$ \\
\hline Constant & $\begin{array}{c}0.326 \\
(0.018)\end{array}$ & $\begin{array}{c}0.402 \\
(0.020)\end{array}$ & $\begin{array}{c}0.194 \\
(0.028)\end{array}$ & $\begin{array}{c}0.322 \\
(0.033)\end{array}$ & $\begin{array}{c}0.023 \\
(0.033)\end{array}$ & $\begin{array}{c}0.208 \\
(0.042)\end{array}$ & $\begin{array}{c}0.505 \\
(0.017)\end{array}$ & $\begin{array}{c}0.643 \\
(0.015)\end{array}$ \\
\hline DC*Change 1994-95 & $\begin{array}{c}-0.001 \\
(0.023)\end{array}$ & $\begin{array}{c}0.006 \\
(0.021)\end{array}$ & $\begin{array}{c}-0.069 \\
(0.033)\end{array}$ & $\begin{array}{c}-0.033 \\
(0.035)\end{array}$ & $\begin{array}{c}-0.018 \\
(0.040)\end{array}$ & $\begin{array}{l}-0.045 \\
(0.047)\end{array}$ & $\begin{array}{c}-0.007 \\
(0.023)\end{array}$ & $\begin{array}{c}0.018 \\
(0.019)\end{array}$ \\
\hline DC*Change 1995-96 & $\begin{array}{c}-0.012 \\
(0.023)\end{array}$ & $\begin{array}{c}-0.012 \\
(0.021)\end{array}$ & $\begin{array}{l}-0.005 \\
(0.033)\end{array}$ & $\begin{array}{c}-0.049 \\
(0.036)\end{array}$ & $\begin{array}{l}-0.023 \\
(0.039)\end{array}$ & $\begin{array}{c}-0.060 \\
(0.047)\end{array}$ & $\begin{array}{c}-0.009 \\
(0.023)\end{array}$ & $\begin{array}{c}-0.021 \\
(0.020)\end{array}$ \\
\hline DC*Change 1996-97 & $\begin{array}{c}0.025 \\
(0.024)\end{array}$ & $\begin{array}{c}0.027 \\
(0.021)\end{array}$ & $\begin{array}{c}-0.026 \\
(0.033)\end{array}$ & $\begin{array}{c}-0.011 \\
(0.037)\end{array}$ & $\begin{array}{c}-0.001 \\
(0.038)\end{array}$ & $\begin{array}{c}0.050 \\
(0.046)\end{array}$ & $\begin{array}{c}0.007 \\
(0.024)\end{array}$ & $\begin{array}{c}0.010 \\
(0.020)\end{array}$ \\
\hline DC*Change 1997-98 & $\begin{array}{c}0.002 \\
(0.023)\end{array}$ & $\begin{array}{c}-0.009 \\
(0.021)\end{array}$ & $\begin{array}{c}0.120 \\
(0.034)\end{array}$ & $\begin{array}{c}0.062 \\
(0.036)\end{array}$ & $\begin{array}{c}0.079 \\
(0.041)\end{array}$ & $\begin{array}{c}0.009 \\
(0.047)\end{array}$ & $\begin{array}{c}0.023 \\
(0.024)\end{array}$ & $\begin{array}{c}0.007 \\
(0.020)\end{array}$ \\
\hline DC*Change 1998-99 & $\begin{array}{c}0.002 \\
(0.024)\end{array}$ & $\begin{array}{c}0.013 \\
(0.021)\end{array}$ & $\begin{array}{l}-0.125 \\
(0.035)\end{array}$ & $\begin{array}{c}-0.093 \\
(0.037)\end{array}$ & $\begin{array}{c}-0.081 \\
(0.044)\end{array}$ & $\begin{array}{c}-0.063 \\
(0.050)\end{array}$ & $\begin{array}{c}-0.014 \\
(0.024)\end{array}$ & $\begin{array}{c}-0.017 \\
(0.020)\end{array}$ \\
\hline DC*Change 1999-2000 & $\begin{array}{c}0.091 \\
(0.023)\end{array}$ & $\begin{array}{c}0.046 \\
(0.020)\end{array}$ & $\begin{array}{c}0.098 \\
(0.035)\end{array}$ & $\begin{array}{c}0.110 \\
(0.038)\end{array}$ & $\begin{array}{c}0.053 \\
(0.043)\end{array}$ & $\begin{array}{c}0.069 \\
(0.050)\end{array}$ & $\begin{array}{c}0.088 \\
(0.023)\end{array}$ & $\begin{array}{c}0.059 \\
(0.020)\end{array}$ \\
\hline DC*Change 2000-2001 & $\begin{array}{c}0.036 \\
(0.022)\end{array}$ & $\begin{array}{c}0.042 \\
(0.018)\end{array}$ & $\begin{array}{c}0.097 \\
(0.037)\end{array}$ & $\begin{array}{c}0.099 \\
(0.036)\end{array}$ & $\begin{array}{c}0.149 \\
(0.045)\end{array}$ & $\begin{array}{c}0.163 \\
(0.047)\end{array}$ & $\begin{array}{c}0.054 \\
(0.022)\end{array}$ & $\begin{array}{c}0.044 \\
(0.017)\end{array}$ \\
\hline Year change dummies & yes & yes & yes & yes & yes & yes & yes & yes \\
\hline State dummies & yes & yes & yes & yes & yes & yes & yes & yes \\
\hline Demographic covariates & yes & yes & yes & yes & yes & yes & yes & yes \\
\hline Observations & 46,972 & 46,972 & 15,178 & 15,178 & 10,458 & 10,458 & 44,245 & 44,245 \\
\hline R-squared & 0.19 & 0.15 & 0.12 & 0.13 & 0.08 & 0.09 & 0.15 & 0.11 \\
\hline
\end{tabular}

(Continued on next page.) 
Table 4 (continued)

Determinants of Whether Students' SAT Scores Sent to at Least One

Out-of-State Public 4-Year College or University; Difference-in-Difference Models, Selected Subgroups

\begin{tabular}{|c|c|c|c|c|c|c|c|c|}
\hline & \multicolumn{4}{|c|}{ Highest Parental Educational Attainment } & \multicolumn{4}{|c|}{$\begin{array}{c}\text { SAT V+M Score } \\
\end{array}$} \\
\hline & \multicolumn{2}{|c|}{ High School or Less } & \multicolumn{2}{|c|}{ Some College or More } & \multicolumn{2}{|c|}{ LE 1000} & \multicolumn{2}{|c|}{ GT 1000} \\
\hline & $\begin{array}{c}\mathrm{MD} / \mathrm{VA} \\
(9) \\
\end{array}$ & $\begin{array}{l}\text { Any } \\
(10) \\
\end{array}$ & $\begin{array}{c}\mathrm{MD} / \mathrm{VA} \\
(11) \\
\end{array}$ & $\begin{array}{l}\text { Any } \\
(12) \\
\end{array}$ & $\begin{array}{c}\mathrm{MD} / \mathrm{VA} \\
(13)\end{array}$ & $\begin{array}{l}\text { Any } \\
(14) \\
\end{array}$ & $\begin{array}{c}\mathrm{MD} / \mathrm{VA} \\
(15) \\
\end{array}$ & $\begin{array}{l}\text { Any } \\
(16) \\
\end{array}$ \\
\hline Constant & $\begin{array}{c}0.426 \\
(0.027)\end{array}$ & $\begin{array}{c}0.415 \\
(0.028)\end{array}$ & $\begin{array}{c}0.250 \\
(0.019)\end{array}$ & $\begin{array}{c}0.412 \\
(0.021)\end{array}$ & $\begin{array}{c}0.327 \\
(0.019)\end{array}$ & $\begin{array}{c}0.331 \\
(0.020)\end{array}$ & $\begin{array}{c}0.224 \\
(0.041)\end{array}$ & $\begin{array}{c}0.665 \\
(0.053)\end{array}$ \\
\hline DC*Change 1994-95 & $\begin{array}{c}-0.041 \\
(0.037)\end{array}$ & $\begin{array}{c}0.028 \\
(0.031)\end{array}$ & $\begin{array}{l}-0.007 \\
(0.022)\end{array}$ & $\begin{array}{c}-0.010 \\
(0.022)\end{array}$ & $\begin{array}{c}-0.025 \\
(0.023)\end{array}$ & $\begin{array}{c}-0.002 \\
(0.020)\end{array}$ & $\begin{array}{c}-0.012 \\
(0.033)\end{array}$ & $\begin{array}{c}-0.011 \\
(0.036)\end{array}$ \\
\hline DC*Change 1995-96 & $\begin{array}{c}-0.021 \\
(0.039)\end{array}$ & $\begin{array}{c}-0.008 \\
(0.032)\end{array}$ & $\begin{array}{c}-0.015 \\
(0.022)\end{array}$ & $\begin{array}{c}-0.040 \\
(0.022)\end{array}$ & $\begin{array}{c}0.001 \\
(0.024)\end{array}$ & $\begin{array}{c}-0.011 \\
(0.020)\end{array}$ & $\begin{array}{c}-0.027 \\
(0.033)\end{array}$ & $\begin{array}{c}-0.055 \\
(0.036)\end{array}$ \\
\hline DC*Change 1996-97 & $\begin{array}{c}0.046 \\
(0.038)\end{array}$ & $\begin{array}{c}-0.026 \\
(0.033)\end{array}$ & $\begin{array}{c}-0.008 \\
(0.023)\end{array}$ & $\begin{array}{c}0.027 \\
(0.023)\end{array}$ & $\begin{array}{c}0.024 \\
(0.024)\end{array}$ & $\begin{array}{c}0.014 \\
(0.021)\end{array}$ & $\begin{array}{c}-0.018 \\
(0.032)\end{array}$ & $\begin{array}{c}0.030 \\
(0.036)\end{array}$ \\
\hline DC*Change 1997-98 & $\begin{array}{c}0.010 \\
(0.037)\end{array}$ & $\begin{array}{c}0.022 \\
(0.032)\end{array}$ & $\begin{array}{c}0.048 \\
(0.023)\end{array}$ & $\begin{array}{c}0.009 \\
(0.023)\end{array}$ & $\begin{array}{c}0.018 \\
(0.024)\end{array}$ & $\begin{array}{c}0.018 \\
(0.020)\end{array}$ & $\begin{array}{c}0.059 \\
(0.033)\end{array}$ & $\begin{array}{c}-0.019 \\
(0.036)\end{array}$ \\
\hline DC*Change 1998-99 & $\begin{array}{c}0.017 \\
(0.037)\end{array}$ & $\begin{array}{c}0.017 \\
(0.032)\end{array}$ & $\begin{array}{c}-0.055 \\
(0.023)\end{array}$ & $\begin{array}{c}-0.026 \\
(0.023)\end{array}$ & $\begin{array}{c}-0.038 \\
(0.024)\end{array}$ & $\begin{array}{l}-0.027 \\
(0.021)\end{array}$ & $\begin{array}{c}-0.029 \\
(0.034)\end{array}$ & $\begin{array}{c}0.017 \\
(0.037)\end{array}$ \\
\hline DC*Change 1999-2000 & $\begin{array}{c}0.037 \\
(0.035)\end{array}$ & $\begin{array}{c}0.001 \\
(0.031)\end{array}$ & $\begin{array}{c}0.114 \\
(0.023)\end{array}$ & $\begin{array}{c}0.088 \\
(0.023)\end{array}$ & $\begin{array}{c}0.110 \\
(0.023)\end{array}$ & $\begin{array}{c}0.072 \\
(0.020)\end{array}$ & $\begin{array}{c}0.070 \\
(0.034)\end{array}$ & $\begin{array}{c}0.051 \\
(0.037)\end{array}$ \\
\hline DC*Change 2000-2001 & $\begin{array}{c}0.044 \\
(0.032)\end{array}$ & $\begin{array}{c}0.044 \\
(0.027)\end{array}$ & $\begin{array}{c}0.062 \\
(0.023)\end{array}$ & $\begin{array}{c}0.061 \\
(0.021)\end{array}$ & $\begin{array}{c}0.028 \\
(0.022)\end{array}$ & $\begin{array}{c}0.024 \\
(0.018)\end{array}$ & $\begin{array}{c}0.101 \\
(0.035)\end{array}$ & $\begin{array}{c}0.115 \\
(0.035)\end{array}$ \\
\hline Year change dummies & yes & yes & yes & yes & yes & yes & yes & yes \\
\hline State dummies & yes & yes & yes & yes & yes & yes & yes & yes \\
\hline Demographic covariates & yes & yes & yes & yes & yes & yes & yes & yes \\
\hline Observations & 21,009 & 21,009 & 41,406 & 41,406 & 47,603 & 47,603 & 14,812 & 14,812 \\
\hline R-squared & 0.25 & 0.18 & 0.12 & 0.11 & 0.22 & 0.18 & 0.07 & 0.08 \\
\hline
\end{tabular}

Source: SAT Score Database.

Notes: All models weighted OLS regressions with heteroskedasticity-consistent standard errors. 
Table 5

Determinants of Number and Share of Scores Sent to DCTAG-Eligible Schools

\begin{tabular}{|c|c|c|c|c|c|}
\hline & \multicolumn{3}{|c|}{ Number of scores sent to } & \multicolumn{2}{|c|}{ Frac. of scores sent to } \\
\hline & $\begin{array}{c}\begin{array}{l}\text { MD or VA } \\
\text { elig. school }\end{array} \\
(1) \\
\end{array}$ & $\begin{array}{c}\begin{array}{c}\text { Any elig. } \\
\text { school }\end{array} \\
(2) \\
\end{array}$ & $\begin{array}{c}\begin{array}{c}\text { Any 4-year } \\
\text { school }\end{array} \\
(3)\end{array}$ & $\begin{array}{c}\text { MD or VA } \\
\text { elig. school } \\
(4)\end{array}$ & $\begin{array}{c}\text { Any elig. } \\
\text { school } \\
(5)\end{array}$ \\
\hline Constant & $\begin{array}{c}0.613 \\
(0.030)\end{array}$ & $\begin{array}{c}1.248 \\
(0.053)\end{array}$ & $\begin{array}{c}1.691 \\
(0.100)\end{array}$ & $\begin{array}{c}0.144 \\
(0.006)\end{array}$ & $\begin{array}{c}0.286 \\
(0.009)\end{array}$ \\
\hline DC*Change 1994-95 & $\begin{array}{l}-0.069 \\
(0.038)\end{array}$ & $\begin{array}{c}-0.074 \\
(0.066)\end{array}$ & $\begin{array}{l}-0.033 \\
(0.112)\end{array}$ & $\begin{array}{l}-0.013 \\
(0.008)\end{array}$ & $\begin{array}{c}0.000 \\
(0.011)\end{array}$ \\
\hline DC*Change 1995-96 & $\begin{array}{c}0.016 \\
(0.039)\end{array}$ & $\begin{array}{c}0.017 \\
(0.068)\end{array}$ & $\begin{array}{c}0.194 \\
(0.113)\end{array}$ & $\begin{array}{c}0.002 \\
(0.008)\end{array}$ & $\begin{array}{l}-0.011 \\
(0.011)\end{array}$ \\
\hline DC*Change 1996-97 & $\begin{array}{c}0.031 \\
(0.040)\end{array}$ & $\begin{array}{l}-0.020 \\
(0.069)\end{array}$ & $\begin{array}{l}-0.092 \\
(0.113)\end{array}$ & $\begin{array}{c}0.013 \\
(0.008)\end{array}$ & $\begin{array}{c}0.016 \\
(0.011)\end{array}$ \\
\hline DC*Change 1997-98 & $\begin{array}{c}0.071 \\
(0.040)\end{array}$ & $\begin{array}{c}0.140 \\
(0.069)\end{array}$ & $\begin{array}{c}0.032 \\
(0.114)\end{array}$ & $\begin{array}{c}0.001 \\
(0.008)\end{array}$ & $\begin{array}{c}0.003 \\
(0.011)\end{array}$ \\
\hline DC*Change 1998-99 & $\begin{array}{l}-0.100 \\
(0.040)\end{array}$ & $\begin{array}{l}-0.162 \\
(0.071)\end{array}$ & $\begin{array}{c}0.072 \\
(0.119)\end{array}$ & $\begin{array}{l}-0.017 \\
(0.008)\end{array}$ & $\begin{array}{l}-0.032 \\
(0.011)\end{array}$ \\
\hline DC*Change 1999-2000 & $\begin{array}{c}0.285 \\
(0.043)\end{array}$ & $\begin{array}{c}0.331 \\
(0.070)\end{array}$ & $\begin{array}{l}-0.014 \\
(0.119)\end{array}$ & $\begin{array}{c}0.048 \\
(0.008)\end{array}$ & $\begin{array}{c}0.068 \\
(0.011)\end{array}$ \\
\hline DC*Change 2000-2001 & $\begin{array}{c}0.121 \\
(0.046)\end{array}$ & $\begin{array}{c}0.307 \\
(0.072)\end{array}$ & $\begin{array}{c}0.261 \\
(0.118)\end{array}$ & $\begin{array}{c}0.022 \\
(0.008)\end{array}$ & $\begin{array}{c}0.040 \\
(0.011)\end{array}$ \\
\hline $\begin{array}{l}\text { Year change dummies } \\
\text { State dummies } \\
\text { Demographic covariates }\end{array}$ & $\begin{array}{l}\text { yes } \\
\text { yes } \\
\text { yes }\end{array}$ & $\begin{array}{l}\text { yes } \\
\text { yes } \\
\text { yes }\end{array}$ & $\begin{array}{l}\text { yes } \\
\text { yes } \\
\text { yes }\end{array}$ & $\begin{array}{l}\text { yes } \\
\text { yes } \\
\text { yes }\end{array}$ & $\begin{array}{l}\text { yes } \\
\text { yes } \\
\text { yes }\end{array}$ \\
\hline $\begin{array}{l}\text { Observations } \\
\text { R-squared }\end{array}$ & $\begin{array}{c}62,415 \\
0.18\end{array}$ & $\begin{array}{c}62,415 \\
0.16\end{array}$ & $\begin{array}{c}62,415 \\
0.12\end{array}$ & $\begin{array}{c}62,415 \\
0.18\end{array}$ & $\begin{array}{c}62,415 \\
0.18\end{array}$ \\
\hline
\end{tabular}

Source: SAT Score Database.

Notes: All models weighted OLS regressions with heteroskedasticity-consistent standard errors. 
Table 6

Fall Enrollment of DC Freshmen Completing High School in Last 12 Months, by School

\begin{tabular}{|c|c|c|c|c|c|c|c|c|c|}
\hline & \multirow[b]{2}{*}{ School name } & \multicolumn{3}{|c|}{ Number of frosh from DC } & \multicolumn{2}{|c|}{ Change, DC frosh } & \multirow{2}{*}{$\begin{array}{c}\text { 2- or 4- } \\
\text { year }\end{array}$} & \multirow{2}{*}{$\begin{array}{l}\text { DCTAG } \\
\text { eligible? }\end{array}$} & \multirow{2}{*}{$\begin{array}{r}\text { State of } \\
\text { school }\end{array}$} \\
\hline & & Fall '96 & Fall '98 & Fall '00 & $1996-98$ & $98-2000$ & & & \\
\hline 1 & Virginia State University & 19 & 16 & 108 & -3 & 92 & 4 & yes & VA \\
\hline 2 & Norfolk State University & 22 & 12 & 60 & -10 & 48 & 4 & yes & VA \\
\hline 3 & Virginia Commonwealth University & 4 & 2 & 22 & -2 & 20 & 4 & yes & VA \\
\hline 4 & Montgomery College of Rockville & 11 & 9 & 27 & -2 & 18 & 2 & yes & MD \\
\hline 5 & Prince Georges Community College & 14 & 16 & 34 & 2 & 18 & 2 & yes & MD \\
\hline 6 & Morgan State University & 13 & 14 & 29 & 1 & 15 & 4 & yes & MD \\
\hline 7 & George Mason University & 12 & 3 & 16 & -9 & 13 & 4 & yes & VA \\
\hline 8 & Johnson C Smith University & 13 & 14 & 27 & 1 & 13 & 4 & & NC \\
\hline 9 & University of Maryland College Park & 11 & 13 & 25 & 2 & 12 & 4 & yes & MD \\
\hline 10 & University of Maryland Eastern Shore & 25 & 18 & 29 & -7 & 11 & 4 & yes & MD \\
\hline 11 & Saint Paul's College & 9 & 5 & 15 & -4 & 10 & 4 & & VA \\
\hline 12 & Columbia University & 17 & 16 & 25 & -1 & 9 & 4 & & NY \\
\hline 13 & Old Dominion University & 1 & 1 & 10 & 0 & 9 & 4 & yes & VA \\
\hline 14 & University of Colorado at Boulder & 3 & 3 & 12 & 0 & 9 & 4 & yes & $\mathrm{CO}$ \\
\hline 15 & University of Pittsburgh-Main Campus & 0 & 0 & 9 & 0 & 9 & 4 & yes & PA \\
\hline
\end{tabular}

(Continued on next page.) 
Table 6 (continued)

Fall Enrollment of DC Freshmen Completing High School in Last 12 Months, by School

\begin{tabular}{|c|c|c|c|c|c|c|c|c|c|}
\hline & \multirow[b]{2}{*}{ School name } & \multicolumn{3}{|c|}{ Number of frosh from DC } & \multicolumn{2}{|c|}{ Change, DC frosh } & \multirow{2}{*}{$\begin{array}{c}\text { 2- or 4- } \\
\text { year }\end{array}$} & \multirow{2}{*}{$\begin{array}{l}\text { DCTAG } \\
\text { eligible? }\end{array}$} & \multirow{2}{*}{$\begin{array}{r}\text { State of } \\
\text { school }\end{array}$} \\
\hline & & Fall '96 & Fall '98 & Fall '00 & $1996-98$ & 98-2000 & & & \\
\hline 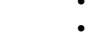 & & & & & & & & & \\
\hline 2897 & University of Georgia & 1 & 6 & 0 & 5 & -6 & 4 & yes & GA \\
\hline 2898 & Vassar College & 5 & 6 & 0 & 1 & -6 & 4 & & NY \\
\hline 2899 & Waynesburg College & 3 & 8 & 1 & 5 & -7 & 4 & & PA \\
\hline 2900 & Bennett College & 11 & 12 & 4 & 1 & -8 & 4 & & NC \\
\hline 2901 & Georgetown University & 10 & 13 & 5 & 3 & -8 & 4 & & DC \\
\hline 2902 & Florida A\&M University & 9 & 18 & 9 & 9 & -9 & 4 & yes & FL \\
\hline 2903 & Strayer College-Washington Campus & 34 & 31 & 22 & -3 & -9 & 4 & & DC \\
\hline 2904 & Cheyney University of Pennsylvania & 3 & 14 & 2 & 11 & -12 & 4 & yes & PA \\
\hline 2905 & Clark Atlanta University & 19 & 21 & 9 & 2 & -12 & 4 & & GA \\
\hline 2906 & Delaware State University & 22 & 38 & 25 & 16 & -13 & 4 & yes & $\mathrm{DE}$ \\
\hline 2907 & Hampton University & 10 & 34 & 21 & 24 & -13 & 4 & & VA \\
\hline 2908 & North Carolina Wesleyan College & 6 & 23 & 8 & 17 & -15 & 4 & & NC \\
\hline 2909 & University of the District of Columbia & 287 & 260 & 245 & -27 & -15 & 4 & & DC \\
\hline 2910 & George Washington University & 86 & 60 & 23 & -26 & -37 & 4 & & DC \\
\hline \multirow[t]{4}{*}{2911} & Howard University & 123 & 86 & 29 & -37 & -57 & 4 & & $\mathrm{DC}$ \\
\hline & Total: MD and VA DCTAG-eligible schools & 188 & 178 & 470 & -10 & 292 & & yes & \\
\hline & Total: All DCTAG-eligible schools & 436 & 487 & 718 & 51 & 231 & & yes & \\
\hline & Total: All schools & 1,870 & 1,775 & 1,893 & -95 & 118 & & & \\
\hline
\end{tabular}

Source: Integrated Postsecondary Data System, 1996-2000.

Notes: Two- and four-year schools reporting freshman enrollment by state of residence in 1996, 1998, and 2000 were included in the tabulation. This set includes 66 MD and VA DCTAG-eligible schools, 1,414 eligible institutions in other states, and 1,431 ineligible schools. 
Table 7

1998 Tuition of Schools with Largest Changes in Freshmen Enrollment of DC Residents

\begin{tabular}{|c|c|c|c|c|c|c|}
\hline & School name & $\begin{array}{l}\text { In-state } \\
\text { Tuition }\end{array}$ & $\begin{array}{c}\text { Out-of-state } \\
\text { Tuition } \\
\end{array}$ & Difference & $\begin{array}{l}\text { DCTAG } \\
\text { eligible? }\end{array}$ & $\begin{array}{c}\text { State of } \\
\text { school }\end{array}$ \\
\hline 1 & Virginia State University & 3,439 & 8,284 & 4,845 & yes & VA \\
\hline 2 & Norfolk State University & 3,335 & 7,540 & 4,205 & yes & VA \\
\hline 3 & Virginia Commonwealth University & 4,182 & 12,666 & 8,484 & yes & VA \\
\hline 4 & Montgomery College of Rockville & 5,070 & 6,762 & 1,692 & yes & MD \\
\hline 5 & Prince Georges Community College & 4,660 & 7,090 & 2,430 & yes & $\mathrm{MD}$ \\
\hline 6 & Morgan State University & 3,706 & 8,810 & 5,104 & yes & MD \\
\hline 7 & George Mason University & 4,344 & 12,504 & 8,160 & yes & VA \\
\hline 8 & Johnson C Smith University & 8,959 & 8,959 & 0 & & NC \\
\hline 9 & University of Maryland College Park & 4,699 & 11,221 & 6,522 & yes & MD \\
\hline 10 & University of Maryland Eastern Shore & 3,585 & 8,227 & 4,642 & yes & MD \\
\hline 11 & Saint Paul's College & 9,780 & 9,780 & 0 & & VA \\
\hline 12 & Columbia University & 23,244 & 23,244 & 0 & & NY \\
\hline 13 & Old Dominion University & 3,476 & 8,900 & 5,424 & yes & VA \\
\hline 14 & University of Colorado at Boulder & 3,038 & 15,520 & 12,482 & yes & $\mathrm{CO}$ \\
\hline 15 & University of Pittsburgh-Main Campus & 6,424 & 13,458 & 7,034 & yes & PA \\
\hline
\end{tabular}

(Continued on next page.) 
Table 7 (continued)

1998 Tuition of Schools with Largest Changes in Freshmen Enrollment of DC Residents

\begin{tabular}{|c|c|c|c|c|c|c|}
\hline & School name & $\begin{array}{l}\text { In-state } \\
\text { Tuition }\end{array}$ & $\begin{array}{c}\text { Out-of-state } \\
\text { Tuition }\end{array}$ & Difference & $\begin{array}{l}\text { DCTAG } \\
\text { eligible? }\end{array}$ & $\begin{array}{r}\text { State of } \\
\text { school }\end{array}$ \\
\hline $2897^{\circ}$ & University of Georgia & 2,930 & 9,860 & 6,930 & yes & GA \\
\hline 2898 & Vassar College & 23,000 & 23,000 & 0 & & NY \\
\hline 2899 & Waynesburg College & 10,970 & 10,970 & 0 & & PA \\
\hline 2900 & Bennett College & 7,905 & 7,905 & 0 & & NC \\
\hline 2901 & Georgetown University & 22,446 & 22,446 & 0 & & DC \\
\hline 2902 & Florida A\&M University & 2,133 & 8,788 & 6,655 & yes & FL \\
\hline 2903 & Strayer College-Washington Campus & 7,695 & 7,695 & 0 & & DC \\
\hline 2904 & Cheyney University of Pennsylvania & 4,023 & 9,379 & 5,356 & yes & PA \\
\hline 2905 & Clark Atlanta University & 9,650 & 9,650 & 0 & & GA \\
\hline 2906 & Delaware State University & 2,974 & 8,104 & 5,130 & yes & $\mathrm{DE}$ \\
\hline 2907 & Hampton University & 10,076 & 10,076 & 0 & & VA \\
\hline 2908 & North Carolina Wesleyan College & 8,144 & 8,144 & 0 & & NC \\
\hline 2909 & University of the District of Columbia & 2,010 & 4,650 & 2,640 & & DC \\
\hline 2910 & George Washington University & 22,625 & 22,625 & 0 & & DC \\
\hline \multirow[t]{4}{*}{2911} & Howard University & 9,155 & 9,155 & 0 & & DC \\
\hline & Average: MD and VA DCTAG-eligible schools & 3,095 & 6,969 & 3,874 & yes & \\
\hline & Average: All DCTAG-eligible schools & 2,294 & 5,739 & 3,445 & yes & \\
\hline & Average: All schools & 6,640 & 8,405 & 1,765 & & \\
\hline
\end{tabular}

Source: Integrated Postsecondary Data System, 1996-2000.

Notes: Two- and four-year schools reporting freshman enrollment by state of residence in 1996, 1998, and 2000 wert included in the tabulation. This set includes 66 Maryland and Virginia DCTAG-eligible schools, 1,414 eligible institutions in other states, and 1,431 ineligible schools. 